\title{
Land-Surface Subsidence and Open Bedrock Fractures in the Tully Valley, Onondaga County, New York
}

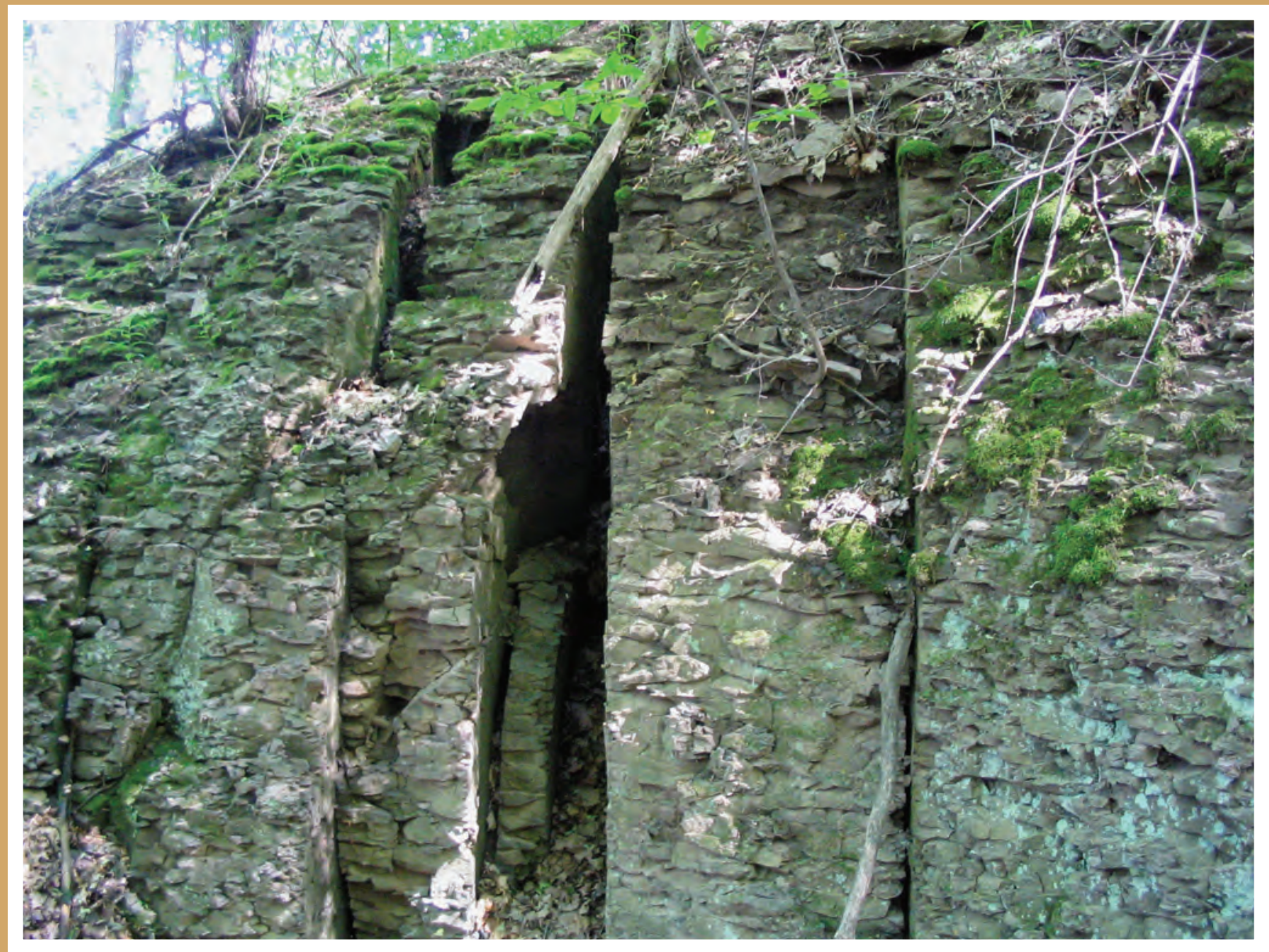

Bedrock fractures have opened in response to subsidence over a former solution-mined area. Subsidence is occurring beyond the left side of the photograph, and has caused these formerly closed bedrock joints to become open bedrock fractures as the rock mass moved to the left.

pen bedrock fractures were mapped in and near two brine field areas in Tully Valley, New York. More than 400 open fractures and closed joints were mapped for dimension, orientation, and distribution along the east and west valley walls adjacent to two former brine fields. The bedrock fractures are as much as 2 feet wide and over 50 feet deep, while linear depressions in the soil, which are 3 to 10 feet wide and 3 to 6 feet deep, indicate the presence of open bedrock fractures below the soil. The fractures are probably the result of solution mining of halite deposits about 1,200 feet below the land surface. 


\section{Introduction}

In the late 1880s, solution mining of halite (rock salt) beds in the southern Tully Valley produced brine used by the Solvay Process Company to manufacture soda ash in Syracuse, N.Y. During the nearly 100 years of solution mining, approximately 150 vertical feet of halite were removed from layers 1,200 feet below the valley floor. Underground solution cavities collapsed, eventually causing land-surface subsidence in the solution-mined areas. The adjacent bedrock valley walls responded to this subsidence by creating open bedrock fractures that follow naturally-formed joint orientations in the bedrock.

The purpose of this report is to document the character of open bedrock fractures and closed joints in relation to regional joint orientations in and near the two brine fields. A brief history of the brine fields and associated subsidence is presented. The fractures and joints are described, and their location and orientation are shown in maps and joint rose diagrams.

\section{Geology of the Tully Valley}

The Tully Valley near Syracuse, N.Y., is a 6-mile-long glacially scoured trough located in the eastern Finger Lakes region of the Allegheny Plateau (fig. 1). The bedrock walls of the valley are Middle Devonian Hamilton Group shales, and the floor of the bedrock valley is Lower Devonian Helderberg Group limestones and dolomites. Upper Silurian Salina Group shales and evaporites, including halite (rock salt) deposits, are about 1,200 to 1,400 feet below land surface at the southern end of the valley. Multiple glacial advances and retreats between 1.6 million and about 11,000 years ago (Rogers, 1991) widened and deepened a pre-existing river valley, and deposited more than 400 feet of clay, silt, sand, gravel, and till in the bedrock trough (Kappel and Miller, 2003).

\section{Tully Valley Brine Field History}

In the late 1880s, the Solvay Process Company established a chemical industry along the southern shore of Onondaga Lake to manufacture soda ash using the region's halite and limestone resources. The concentration of salt in brine springs and wells along the shores of Onondaga Lake diminished due to nearly 130 years of brine withdrawal (1790s to late 1920s) for soda-ash production, forcing the Solvay Process Company to find a new source of brine (Kappel, 2000). A number of deep exploratory boreholes were drilled and halite was found at a depth of 1,200 feet below land surface in the southern end of the Tully Valley about 15 miles south of Syracuse (fig. 1).

Solution mining began in the Tully Valley in 1888. Initially, solution-mining wells were drilled into the uppermost halite layer (about 45 feet thick) in several well clusters within the east and west brine fields (fig. 2). Three additional halite beds were discovered below the first bed, and these additional beds were solution mined as the soda ash industry grew. Solution-mining wells are used to extract salt by pumping freshwater into the halite bed, dissolving the halite into saturated brine, then pumping the brine from the dissolution cavity. This method of brine removal was made more efficient through the "undercut method"-injecting water into the lower beds while connected to the upper, previously solutioned beds that already contained partially saturated brine. Additionally, drilling wells to follow the natural dip of the halite beds (dipping to the south) allowed the dissolution cavities to connect in a downslope

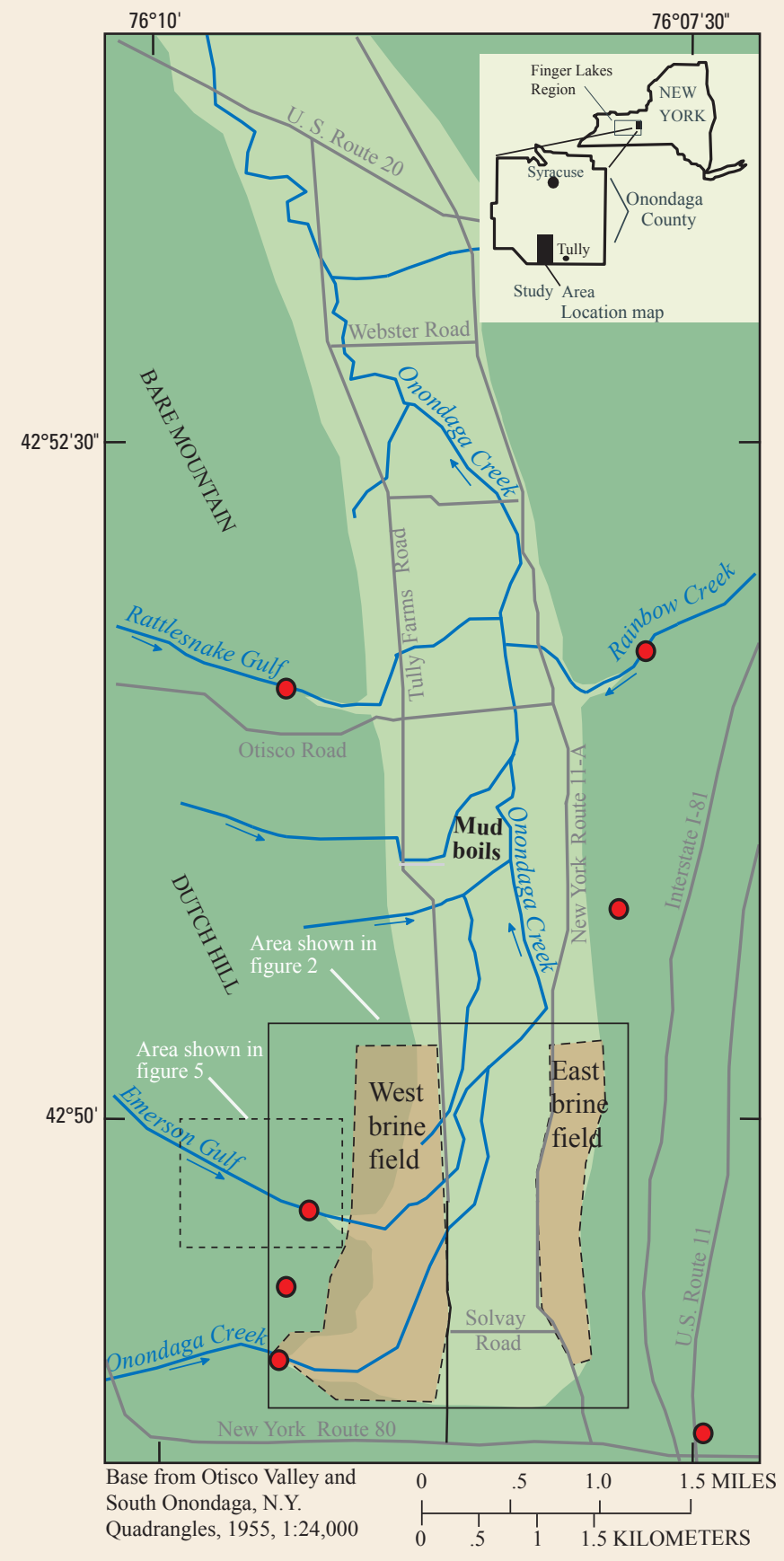

\section{EXPLANATION}

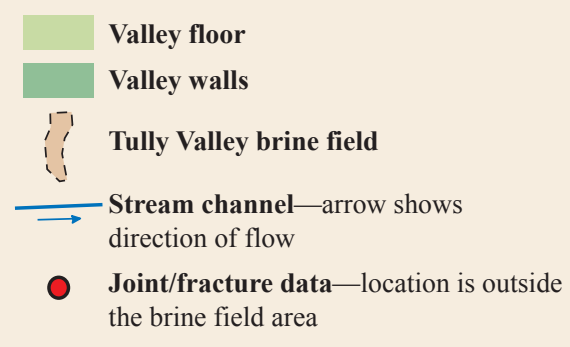

Figure 1. Physiographic features in the Tully Valley, Onondaga County, N.Y. 


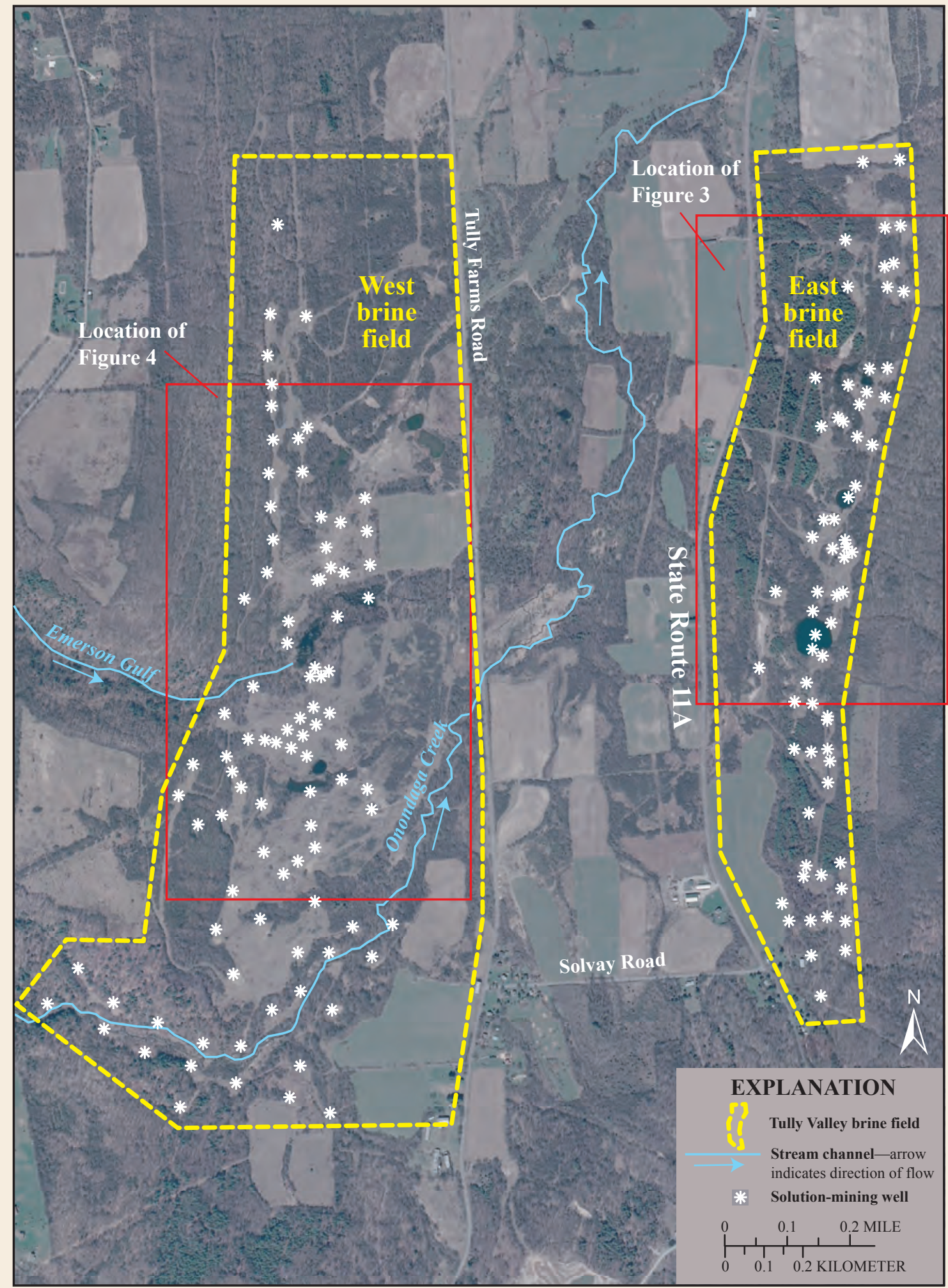

North American Datum of 1983; Universal Tranverse mercator projection, Zone 18N;

Orthoimage base from New York State Office of Cyber and Critical Infrastructure Coordination, Spring 2006.

Figure 2. Locations of solution-mining wells in the Tully Valley brine field, Onondaga County, N.Y. (Location shown in figure 1.) 
direction as new solution-mining wells were drilled farther to the north, further increasing brine-removal efficiency (Yanosky and Kappel, 1998). Early solution mining techniques did not leave walls or pillars of halite to support the overlying bedrock and, therefore, increased the possibility of bedrock collapse within the solutioned halite layers as well as in the overlying bedrock.

Brine production in the Tully brine fields peaked during 1950-60, before the east brine field was closed in 1960 due to the amount of land-surface subsidence that had occurred in this field. The west brine field was used for production until 1988. During the 94-year history of brine removal, more than 160 solution-mining wells were drilled (fig. 2) and more than 96 million tons or approximately 31,000 acre-feet of halite were removed from the southern Tully Valley_enough to fill Syracuse University's Carrier Dome sports complex 35 times (Kappel, 2000).

\section{Subsidence History in the Brine Field}

Collapse within solution cavities occurred early in the brine mining process. In a historic retrospective of the Tully brine field written in 1950, the subsidence problem was described (The Solvay Process Company, 1950).

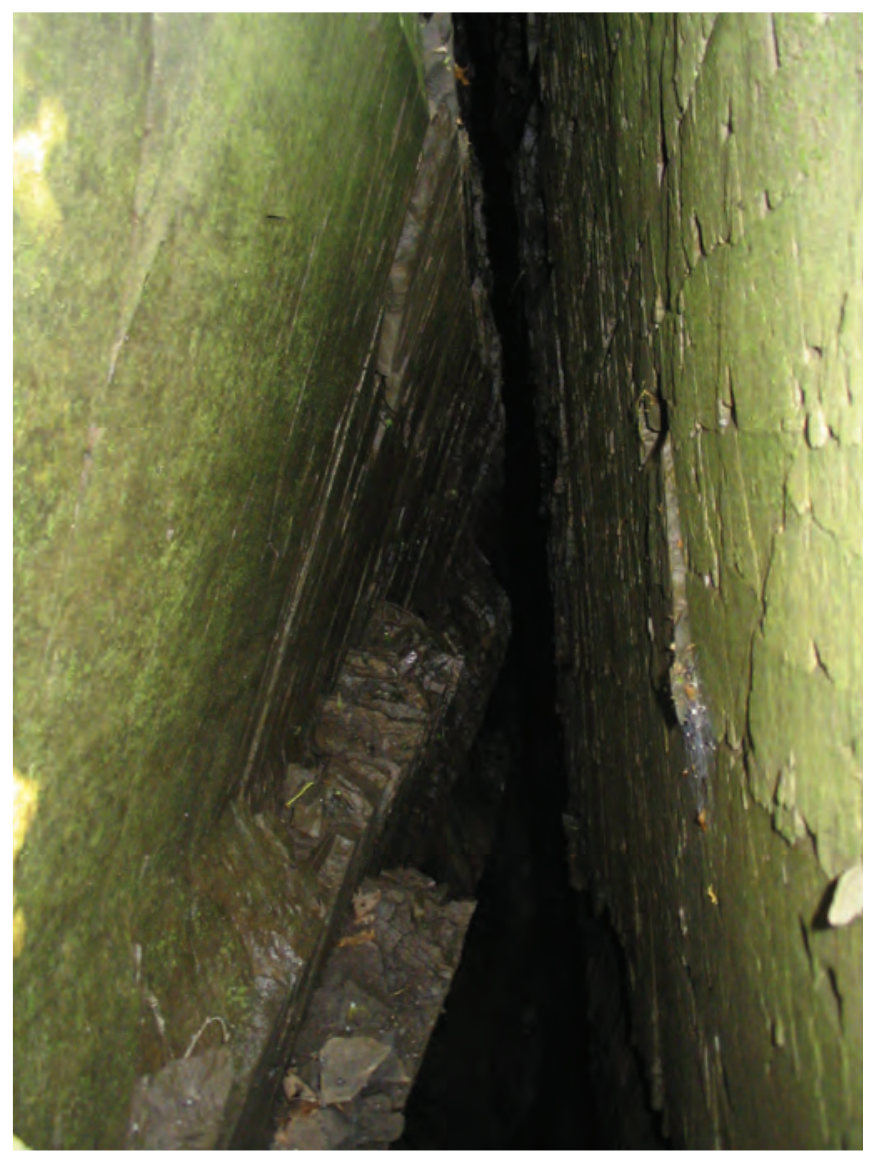

Looking downward into an open bedrock fracture which is about 30 feet deep. The left face has pulled away from the right face of the bedrock fracture in response to land-surface subsidence in the former brine field.
"During the years 1889 and 1890, thirty-one wells were drilled along the east side of the valley and extending about a mile and a half northerly from the first well. ***Most of the East Side wells, however, were drilled thru [sic] the top salt bed only, and because this bed was only 40 to 50 feet thick, it was necessary, in order to obtain suitable capacity for strong brine, to feed water to the top of the salt bed and to draw brine from the bottom. Because of this, and because there is 150 feet of Shale Rock immediately above the top salt, early and frequent caving [rock falling from the roof of the brine cavities] resulted."

This report (The Solvay Process Company, 1950) also indicates that in 1929, a new method of air-padding (placing a volume of air at the top of the solution chamber to prevent the removal of halite from the roof and the collapse of the overlying bedrock) and drilling "undercut" wells in the lower halite layers was used to further increase brine production. The "undercut method" was initially successful in producing greater quantities of brine, but cavern collapse and subsequent subsidence of the land surface in the east brine field was noted.

"For the past several years [1940s] a general subsidence of the ground has been noted at the

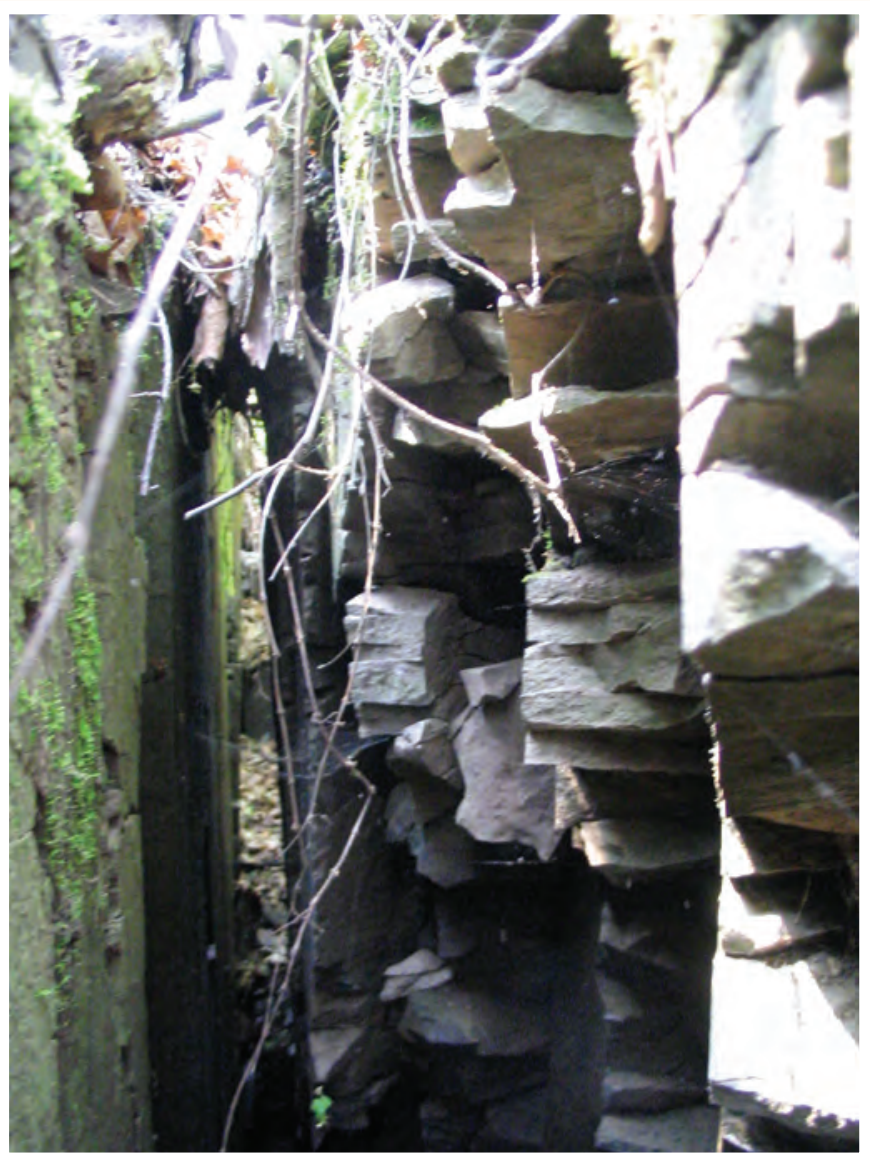

An open fracture showing the uphill face on the left and the downhill face on the right. The saw-tooth pattern of the right face of the fracture shows the close proximity of two intersecting joint sets in the bedrock. 
east side wells but more particularly in the vicinity of the S-1, S-2 group of undercut wells. In 1943 , it was noted that fissures were being opened up in the rock on the side hill along these wells. ***In January, 1949, without any previous warning, the ground at the north of D-Group, in the vicinity of the S-3, S-4, S-5 undercut wells suddenly dropped down***. This "Sink Hole" is about 200 feet in diameter and 60-65 feet, deep and filled up with fresh water. $* * *$ a gradual subsidence still continues toward the side hill***."

A 1960 Tully Brine Field report indicated that subsidence was an early problem (The Solvay Process Company, 1960).

"It has been noted as early as 1928 that when the ' $\mathrm{C}$ ' Group wells were drilled up on the hillside [East Field area], subsidence encountered from the lower ' $C$ ' wells caused the shale on the hillside to creep towards the area of subsidence. This effectively cut off or plugged uphill wells." Further on: "By using this method of top feeding [slotting a well casing above the top halite layer and allowing a concentrated brine from the upper halite chamber to flow down into the lower halite

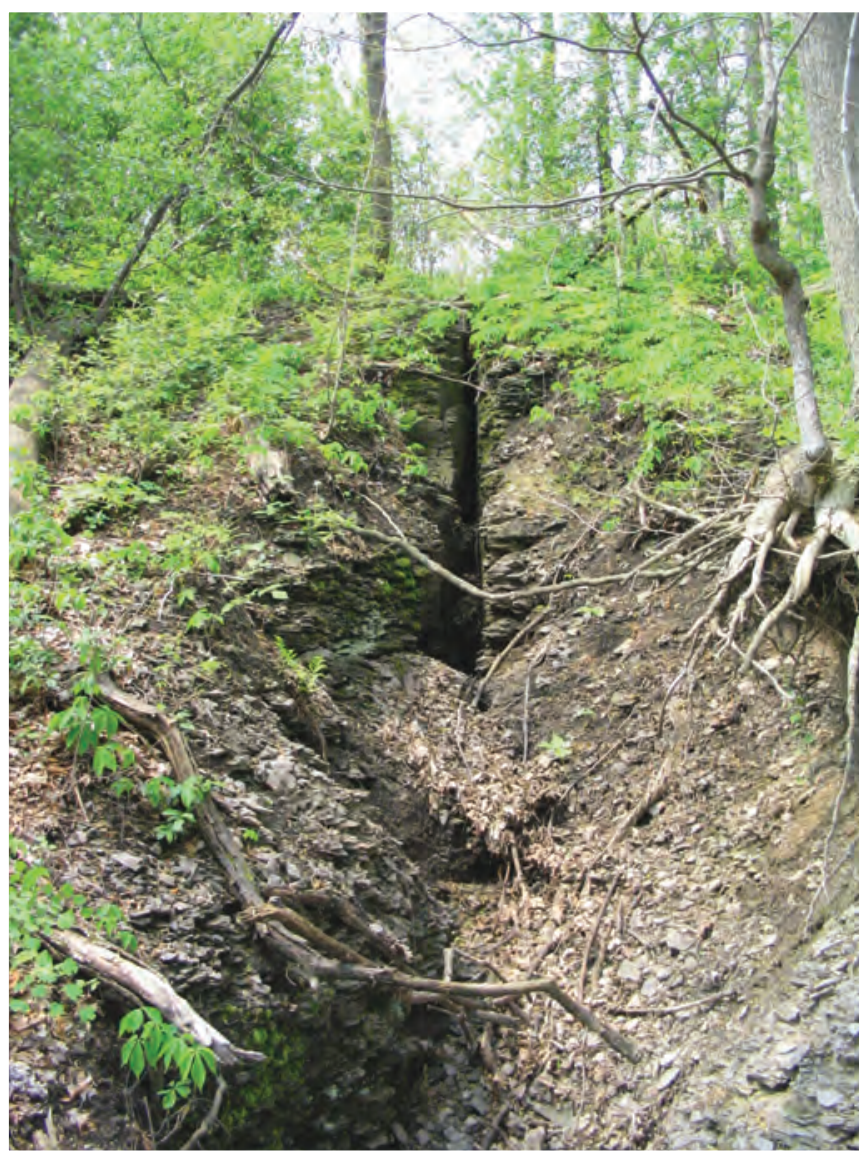

Open bedrock fracture adjacent to the west brine field, showing an open bedrock fracture above, with soil still bridging the open fracture below. layers] it is probably [sic] that we weakened and widened the overall top support for the field, and this allowed for the top to cave in. These generally subsided gradually and only the areas where brine [halite] had been removed from the lower level through the upper level where large sink holes developed."

Some areas on the valley floor subsided as much as 40-50 feet over several decades (CS Consulting Engineers, 1992). Subsidence observed on the valley floor above each brine field was widespread, and open bedrock fractures appeared upslope on the valley walls. (In this report, "closed joint" indicates a natural crack or joint that is visible only as a thin crack in the bedrock surface, and "open fracture" indicates a closed crack or joint that has opened by several inches or feet to reveal two opposing bedrock walls.)

\section{Regional Bedrock Fracture Pattern}

Exposed bedrock along the Tully Valley walls have closed joints (cracks) that are parallel to joint sets of the broader Finger Lakes region. Parker (1942) documented three orientations of joints: Set I striking roughly N. $10^{\circ} \mathrm{W}$., Set II striking roughly east-west, and Set III striking roughly N. $65^{\circ}$ E. in central

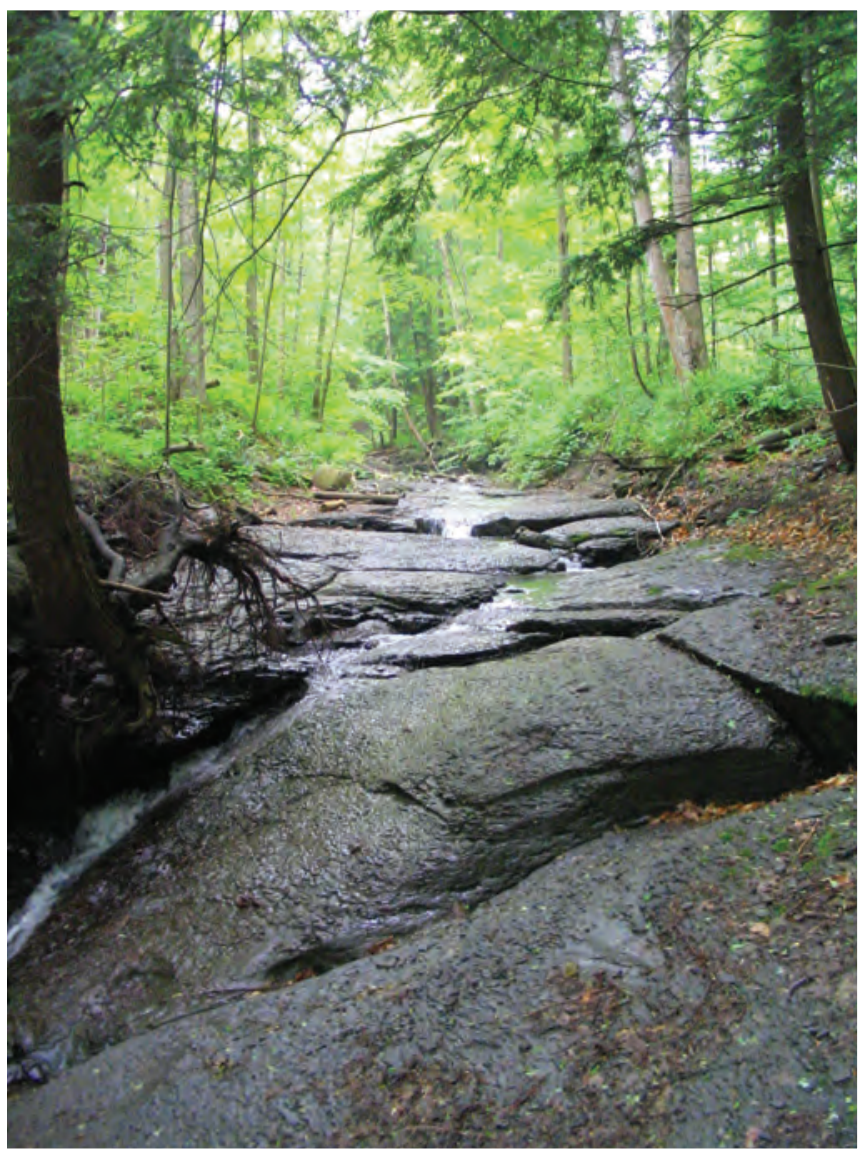

Bedrock floor of Emerson Gulf above the Tully Valley, showing the influence of closed bedrock joints on the erosion of the bedrock surface. This section of stream channel does not lose flow to the closed joints. 
New York. Sets I and II likely developed during the Alleghanian Orogeny (the collision of the African and North American continents between 320 and 260 million years ago), as they have a geometric relation to other geologic structures of that time (Parker, 1942; Engelder and Geiser, 1980). The origin of Set III is problematic. Detailed work on the Set III joints in the Finger Lakes region of New York revealed that these joints are offset by Sets I and II, and thus pre-date the Alleghanian Orogeny (Engelder and others, 2001). These closed bedrock joint sets are ubiquitous in the region, and pre-date the glacial origin of the valley.

\section{Land-Surface Subsidence}

Land-surface subsidence in the Tully Valley has occurred in various forms and is related to several different geologic processes. In the brine-field area, the removal of a composite 150 -foot thickness of halite at depths greater than 1,200 feet below land surface without leaving any physical support within the solution cavities causes two general types of subsidence. Large, broad-scale subsidence known as "bulking subsidence" (Fernández, 1992) causes a gentle sagging of the entire bedrock sequence and overlying land surface that can occur over a period of years to decades. This type of land-surface subsidence can range from a few feet to a few tens of feet over an area of tens to hundreds of acres. A second, more localized, smaller-scale subsidence known as "chimney subsidence" (Fernández, 1992) generally forms sink-like depressions in the land surface over a period of hours to days. The resulting sinkhole can be tens of feet deep and limited initially to an area of just a few acres, but can grow deeper and wider over time to cover tens of acres.

Land-surface subsidence is generally described by terms related to vertical and horizontal movement seen at the land surface. Van Sambeek (1996) described these terms as subsidence, slope, curvature, and horizontal strain. The last term describes the compression or extension of the ground due to differential horizontal movement. Generally, compressive horizontal strain (causing buckling and bowing) occurs inside the perimeter of the mine (or solution cavity in the Tully Valley), and tensile strain (causing separation and cracking) occurs just outside the mine or solution-cavity perimeter (fig. 3). During the nearly 100 years of solution mining and related land-surface subsidence in the Tully Valley, the bedrock adjacent to the brine fields developed open fractures along orientations of formerly closed bedrock joints (fig. 4) as a result of tensile strain as the collapse of bedrock has progressed from the solution cavity up to the land surface.

\section{Investigation of Open Fractures in the Tully Valley}

Aspects of surface subsidence and related fractures in the Tully Valley area such as the dimensions, orientations, and distribution of the open fractures, were mapped along the east and west valley walls adjacent to the brine fields (figs. 5 and 6 , respectively). The open fractures can be seen clearly in the bedrock or observed as linear depressions in the shallow, overlying soil. Open bedrock fractures are from 0.33 to 2 feet wide and from 2 to more than 50 feet deep. Linear depressions in the soil typically are 3 to 10 feet wide, and 3 to 6 feet deep. These linear depressions reflect collapse of soil into an open bedrock fracture and can exhibit "bridges" of soil between open

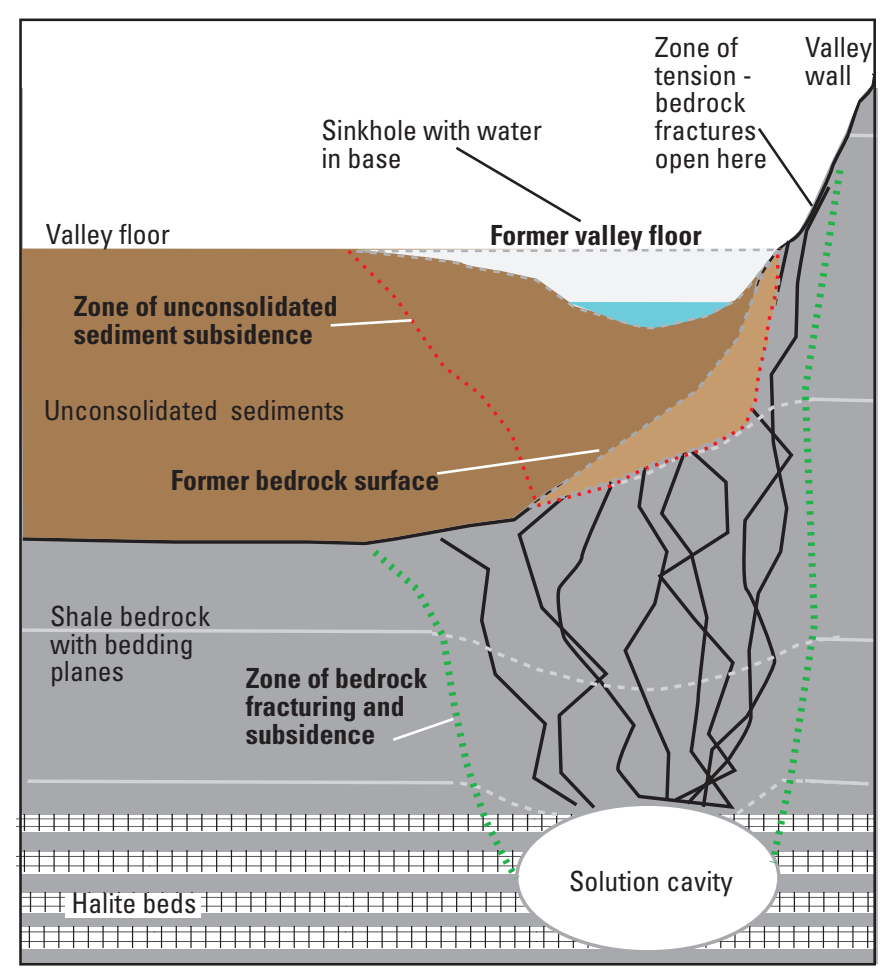

Figure 3. Conceptual drawing of subsidence under the floor of the Tully Valley, Onondaga County, N.Y., due to solution mining of deep halite layers, showing sag and subsidence in the bedrock above the solution cavity, the resulting sag at the land surface, and the opening of bedrock fractures along a "zone of tension" along the adjacent valley wall.

gaps where the soil has fallen into the fracture, locally known as "coffin holes." The total lengths of all linear features can range from tens of feet to more than 500 feet. On both sides of the valley, the open bedrock fractures generally are limited to the lower portion of each slope - below an altitude of about 910 feet along the east valley wall, and below an altitude of about 970 feet along the west valley wall.

\section{Brine Field Open Fractures and Valley- Floor Subsidence}

Fractures are present along the perimeters of both brine fields - more than 400 open fractures and closed joints were mapped adjacent to the two brine fields (see the Joint Rose sidebar). The dominant set of open fractures strikes just west of north corresponding to Set I of Parker (1942) (see figure SB1-1 in the joint rose sidebar.) A less prevalent set strikes approximately N. $60^{\circ}-70^{\circ}$ E., corresponding to Set III of Parker (1942), and a few east-west striking fractures also were recorded corresponding to Set II of Parker (1942). The orientation of open fractures and closed joints outside the brine field area are shown in figure SB1-2; the orientation of fractures and joints in the west and east brine fields are shown in figures SB1-3 and SB1-4, respectively. 


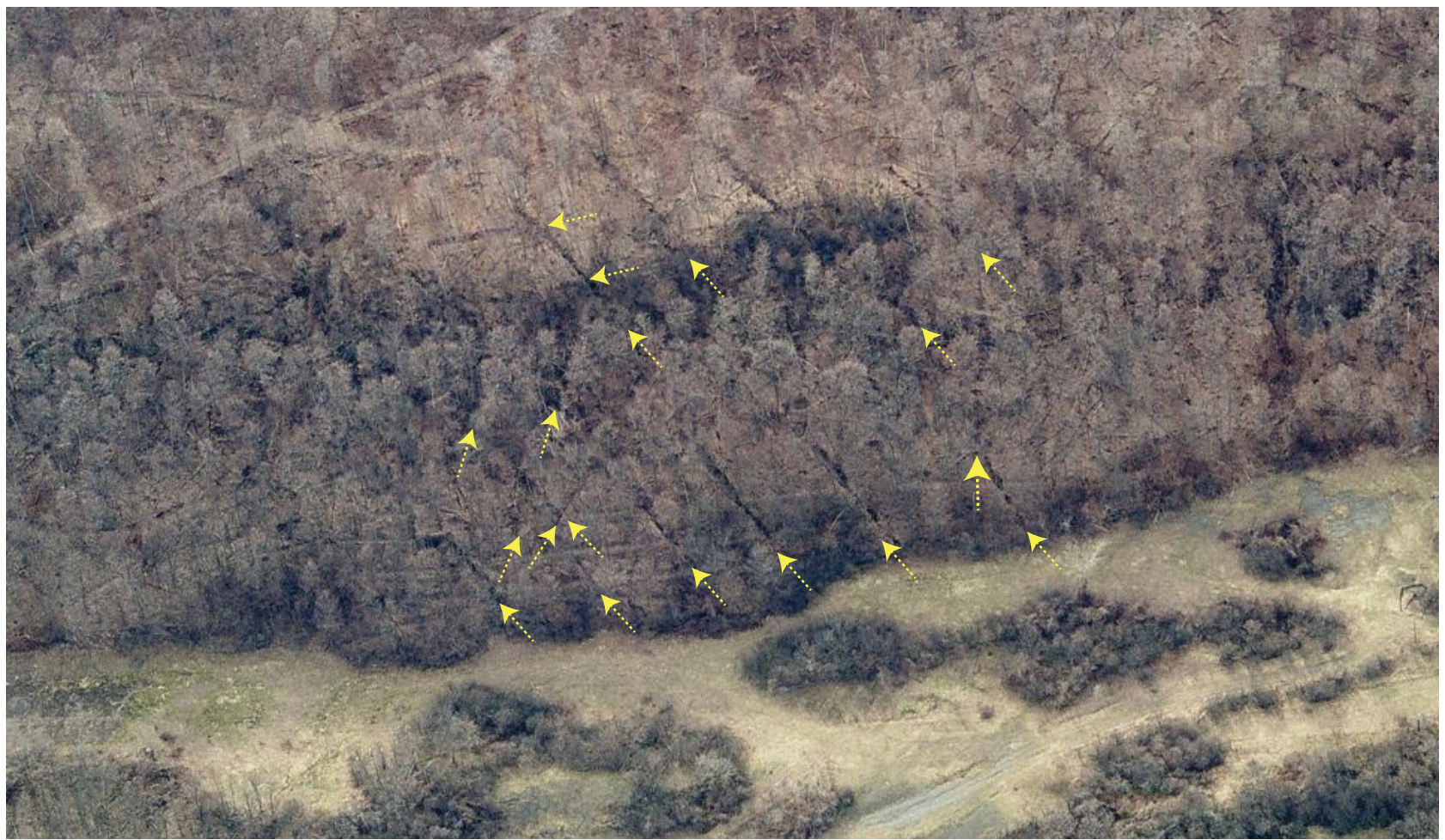

Imagery by Pictometry International Corporation

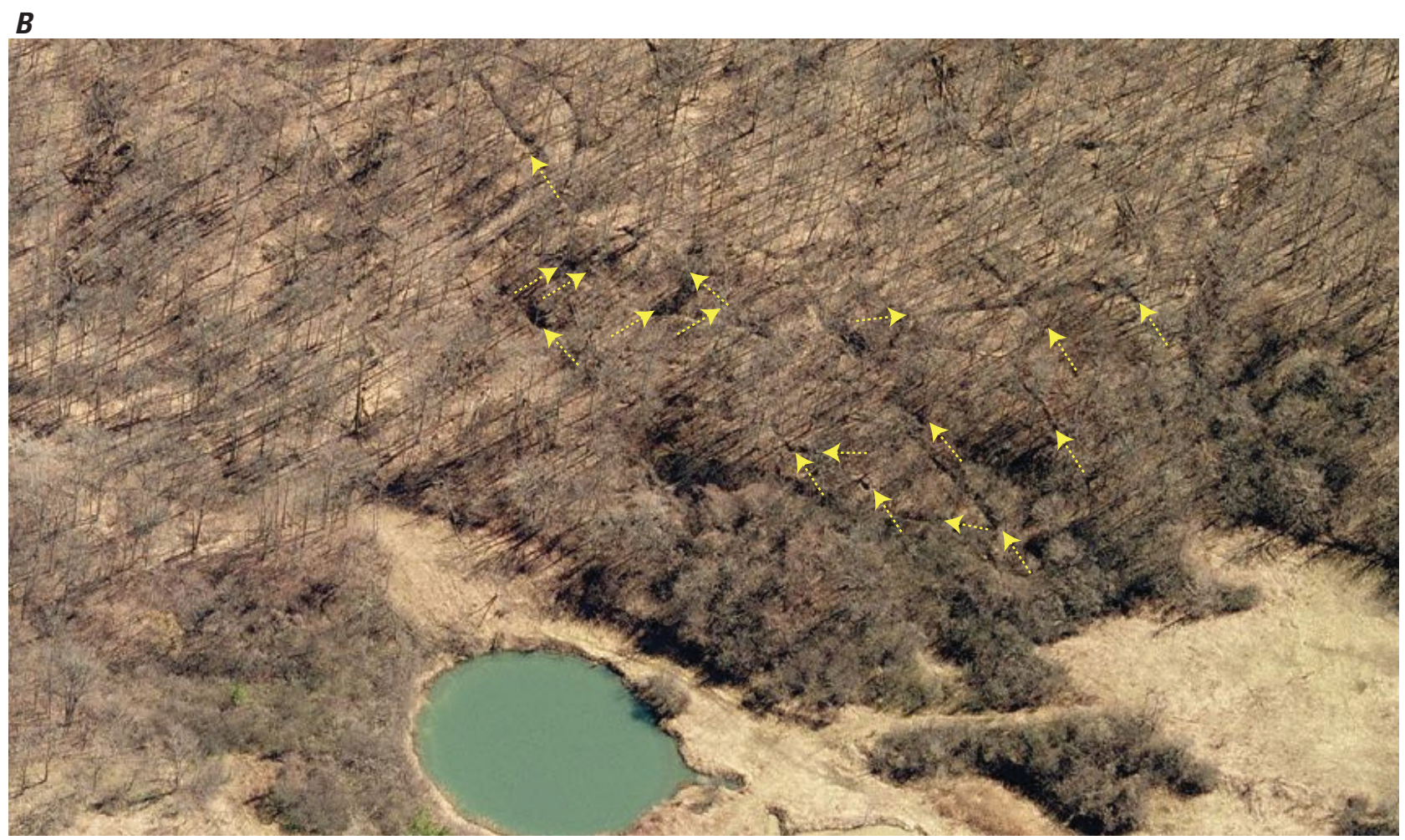

Imagery by Pictometry International Corporation

Figure 4. Major fractures above the Tully Valley brine fields: $(A)$ near the north end of west brine field and $(B)$ above the central sinkhole in the east brine field, Onondaga County, N.Y. (Arrows indicate location and orientation of large fractures on the lower hillside above each brine field.) 


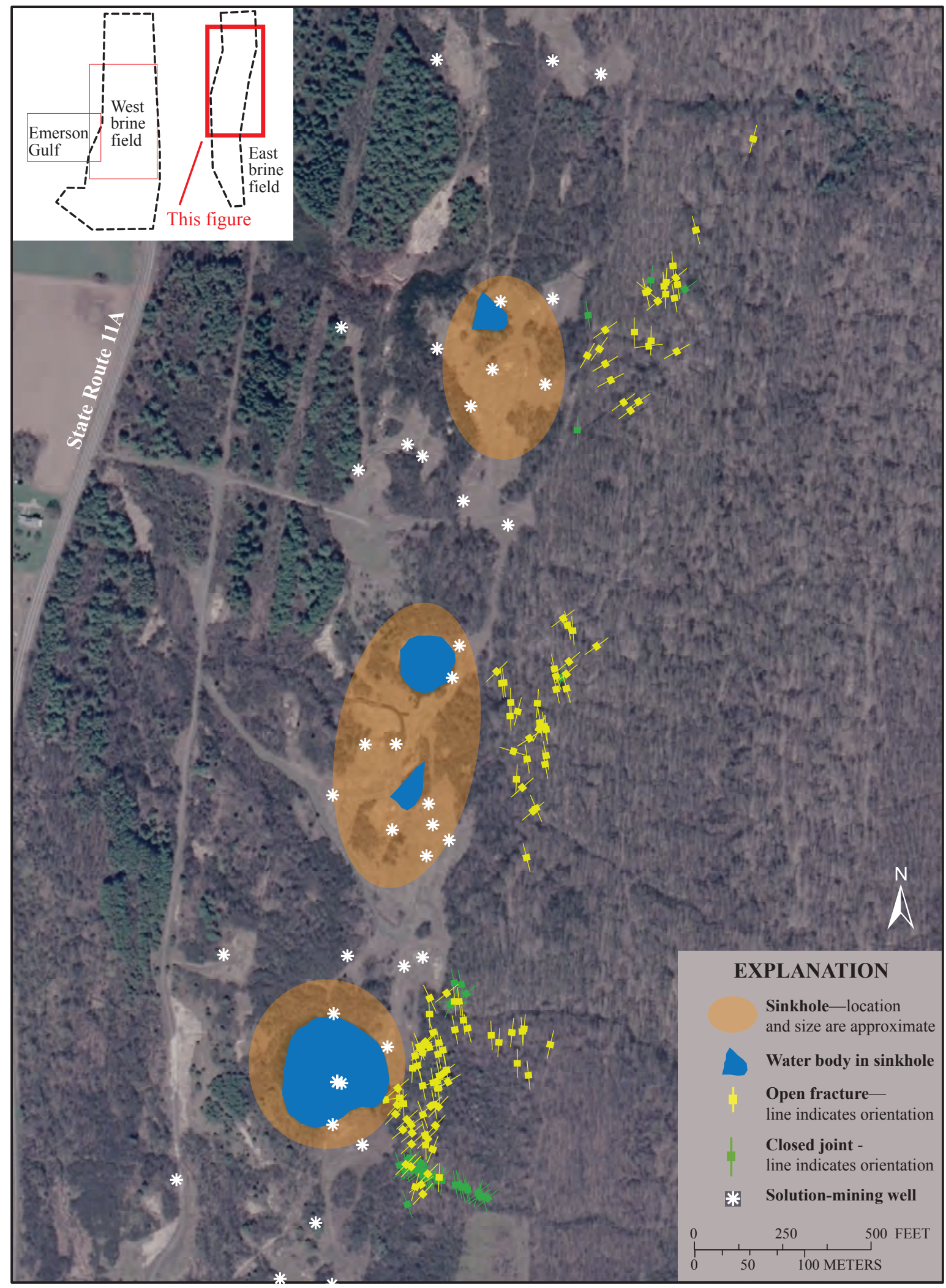

North American Datum of 1983; Universal Tranverse mercator projection, Zone 18N

Orthoimage base from New York State Office of Cyber and Critical Infrastructure Coordination, Spring 2006.

Figure 5. Location of open fractures and closed joints upslope from land-surface subsidence and sinkholes in the east brine field of the Tully Valley, Onondaga County, N.Y. (Location shown in figure 2.) 


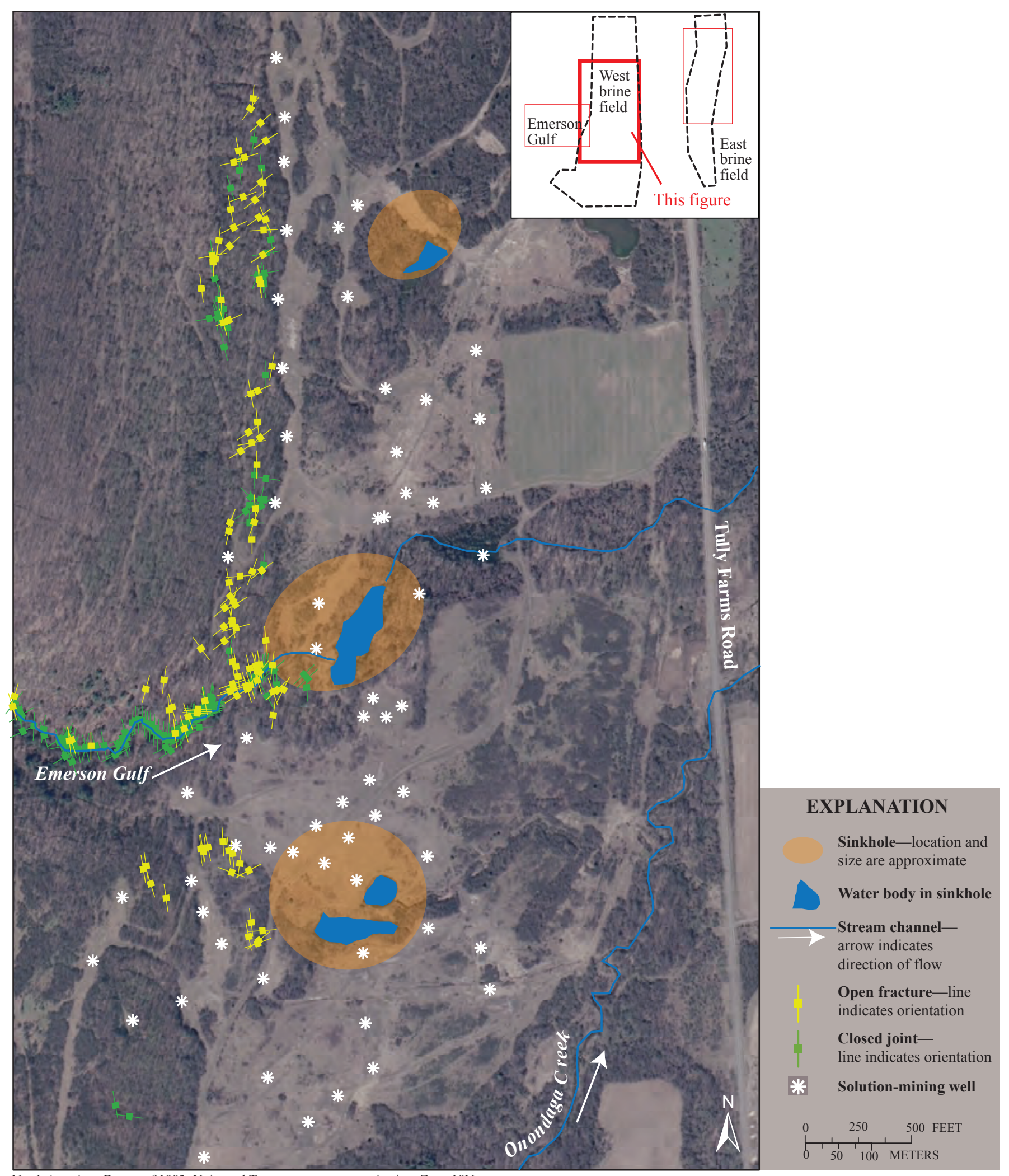

North American Datum of 1983; Universal Tranverse mercator projection, Zone 18N;

Orthoimage base from New York State Office of Cyber and Critical Infrastructure Coordination, Spring 2006.

Figure 6. Location of open fractures and closed joints upslope of land-surface subsidence and sinkholes in the west brine field of the Tully Valley, Onondaga County, N.Y. (Location shown in figure 2.) 


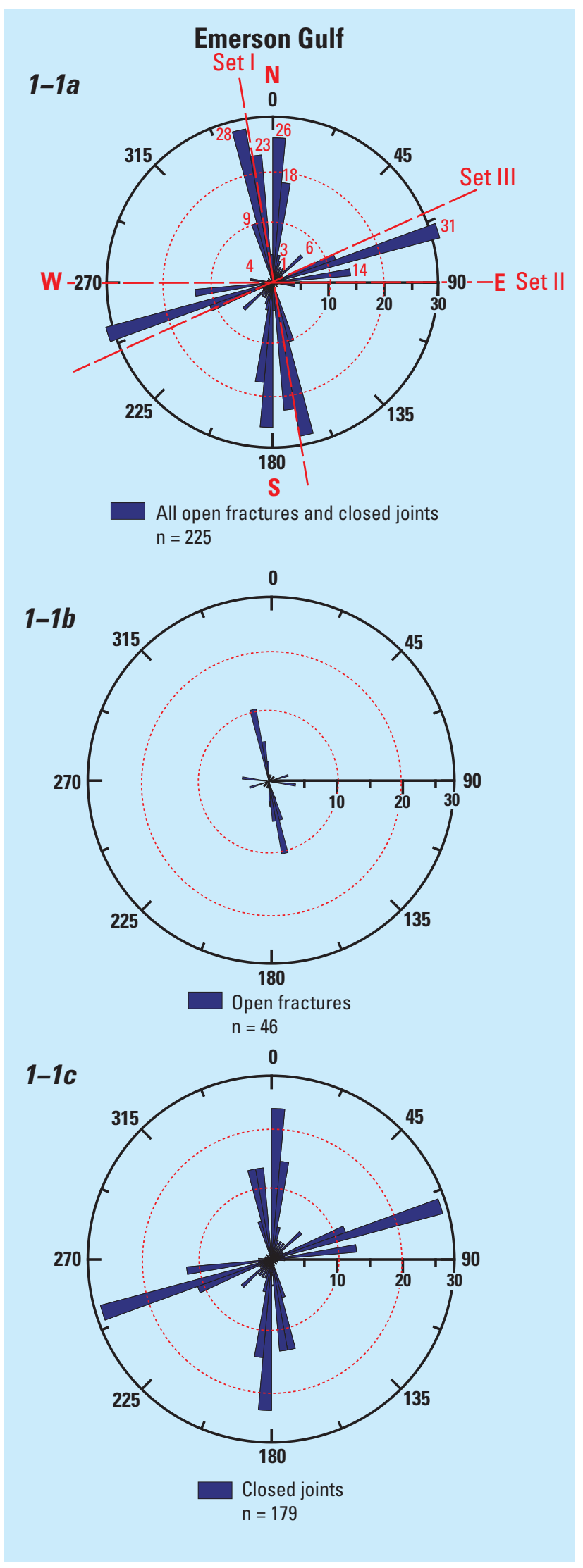

Figure SB1-1. Orientation of open fractures and closed joints in the Emerson Gulf stream channel, Tully Valley, Onondaga County, N.Y.

\section{A Rose by any other name is but a Rose.....}

Joint rose diagrams are used by geologists to display field data, in this case the orientation and number of joints or fractures found in the bedrock in and around the Tully Valley. Each rose diagram is broken into 5-degree compass increments, and the number of joints present within each increment is indicated by the distance from the center of the joint rose. All compass orientations are measured east or west of north - for consistency, the mirror image of these readings is shown in the southern half of the joint rose diagram.

Three major joint orientations were mapped by Parker (1942) for the Finger Lakes region: Set I strikes roughly N. $10^{\circ} \mathrm{W}$.; Set II strikes roughly east-west; and Set III strikes roughly N. $65^{\circ}$ E. In the Emerson Gulf-All Fractures and Joints rose diagram (sidebar figure SB1-1a, upper left), the three major joint orientations, number of joints and fractures, and compass directions are shown. For all the rose diagrams presented in this report, joint Sets I and III appear to be well represented, while several other orientations are also present.

The open bedrock fractures present adjacent to the brine field generally follow these preferred joint orientations and are a natural response to solution-mining-induced subsidence and subsequent sinkhole development.

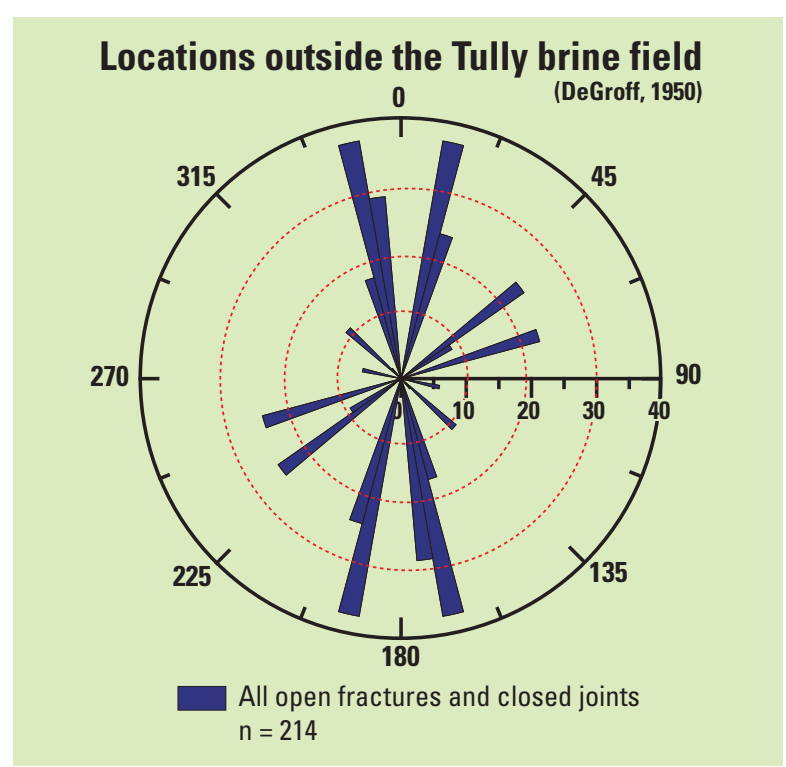

Figure SB1-2. Orientation of open fractures and closed joints for locations outside the Tully brine field area, Tully Valley, Onondaga County, N.Y. 


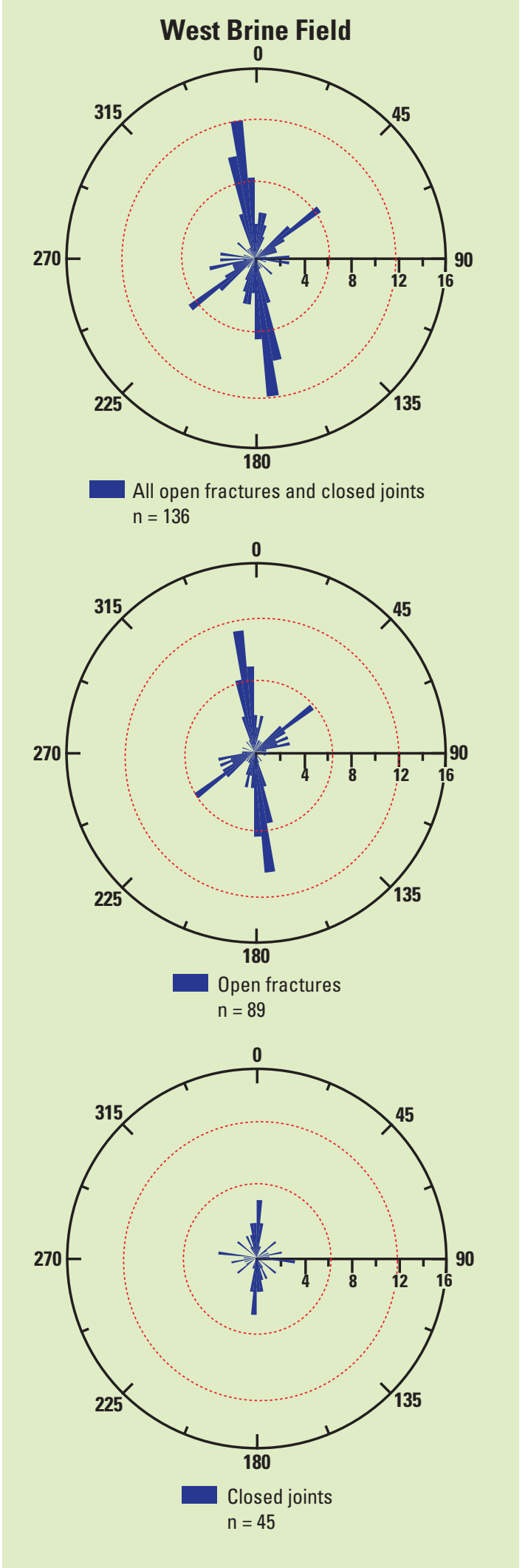

Figure SB1-3. Orientation of open fractures and closed joints in the west brine field area, Tully Valley, Onondaga County, N.Y.
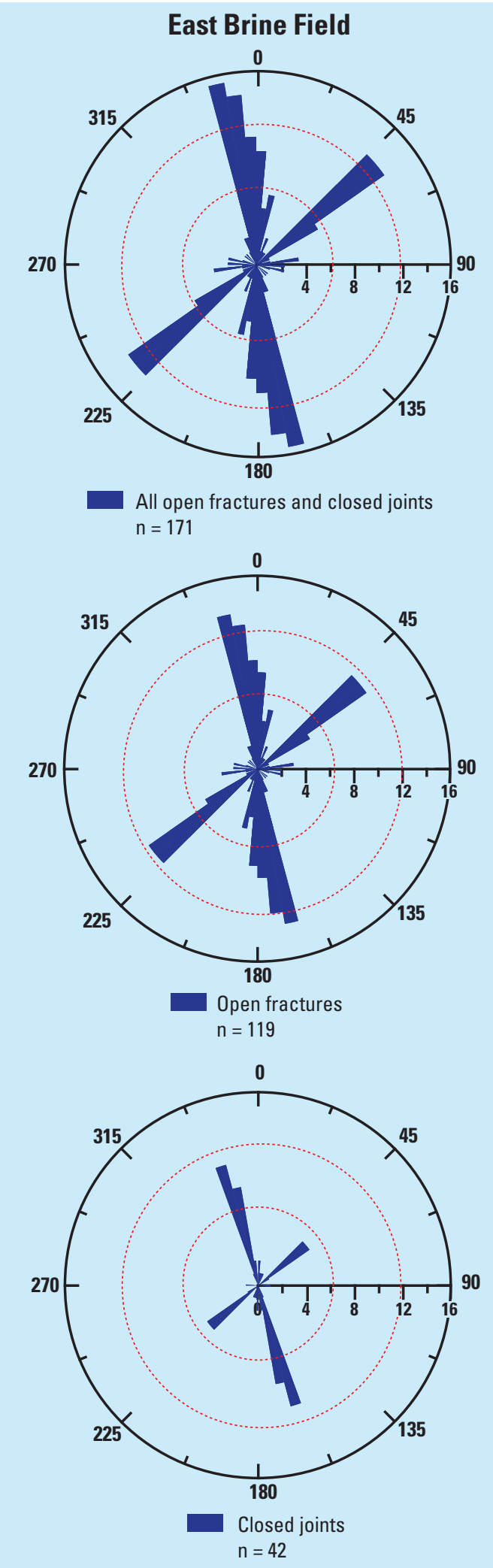

Figure SB1-4. Orientation of open fractures and closed joints in the east brine field area, Tully Valley, Onondaga County, N.Y. 
In the east brine field, open fractures are grouped adjacent (just uphill to the east) to three sinkhole areas (fig. 5). In the west brine field, a similar relation between open fractures and sinkhole development is noted where bedrock fractures are grouped adjacent (just uphill to the west) to the three major sinkholes (fig. 6), although along the west valley wall, the open fractures are present in a more consistent pattern near the sinkholes. Neither brine field has substantial open bedrock fractures to the north or south of the current sinkholes despite the presence of many former solution-mining wells north or south of the major sinkhole areas. The location of the sinkholes is north of a reported east-west trending geologic structure within the halite unit; the structure is possibly associated with salt deformation near the northern edge of the halite deposition margin, typically described as a décollement or sliding surface created by the halite (Rickard, 1977). CS Consulting Engineers (1992) reported that the halite beds are thicker to the north of this structure and are thinner to the south as the sliding surface may have "piled up" salt that was south of the structure and pushed it into the salt north of the structure. Therefore, in the area with a thicker sequence of halite, larger halite cavities were formed, which affected the amount and degree of overlying bedrock subsidence, and created the sinkhole areas and subsequent fracturing of adjacent bedrock. CS Consulting Engineers (1992) reported that this structure, a possible reverse fault, is aligned roughly N. $74^{\circ} \mathrm{W}$., nearly parallel with and south of Solvay Road (figs. 1 and 2).

The only open fractures observed outside of the east and west brine fields are about 2 miles north of the east brine field at nearly the same altitude. A small cluster of open fractures was first reported by Robert Snavlin in 1948 to be present east of his farm (Robert Snavlin, private citizen, written commun., 1968). These fractures are similar to the open brine field fractures in all aspects except that they are not associated with any sinkhole development farther downslope from them.

\section{Other Joints and Fractures Mapped near the Brine Field Area}

Joints and fractures within and adjacent to the Tully Valley were mapped by DeGroff (1950), and their orientations are displayed in the rose diagram (fig. SB1-2). Fracture orientations in three stream valleys (Rattlesnake Gulf, Rainbow Creek, and Onondaga Creek at Fellow Falls) and a bedrock outcrop along U.S. Route 11 just north of New York Route 80 (fig. 1) were compared to the fracture orientations in the two brine fields (figs. SB1-3 and SB1-4). Results of the DeGroff (1950) analysis of all fractures and joints (open and closed) within and adjacent to the Tully Valley (SB1-2), indicate that joint orientations are similar to those mapped in the brine fields (figs. SB1-3 and SB1-4) and to those mapped throughout the Finger Lakes region by Parker (1942).

In a fourth stream valley at Emerson Gulf (figs. 1 and 7), mostly closed joints and some open fractures were mapped (SB1-1). Although many of the joints were mapped near the western wall of the Tully Valley opposite one of the large sinkholes in the west brine field (fig. 6), other joints and fractures are present at least 3,000 feet upstream on Emerson Gulf to near the intersection with Woodmancy Road (fig. 7). Nearly 75 percent of the 225 joints and fractures mapped in the stream channel (fig. SB 1-1) are closed joints, in contrast to the joint/fracture relation in the east and west brine fields where 24 to 33 percent were closed joints (figs. SB1-3 and SB1-4). Reaches of the Emerson Gulf stream also lose water, presumably through open fractures on the floor of the channel (fig. 7-red polygons). Streamflow measurements were made to document losing reaches along Emerson Gulf, although similar measurements along the Onondaga Creek channel to the south indicated no loss of water along its length. No measurements could be made in the east brine field area because of the lack of perennial streams draining the east valley wall near the east brine field. The heavily fractured nature of the Emerson Gulf bedrock channel may be related to the previously noted reverse faulting bedrock structure (CS Consulting Engineers, 1992) whose orientation roughly strikes parallel to the Emerson Gulf tributary valley (fig. 1). A large number of Set III joints (Parker, 1942) are also found in the Emerson Gulf valley.

\section{Summary}

As a result of the removal of large volumes of halite from the brine field by solution mining of the upper halite bed, the roofs of the solution cavities caved in soon after solution mining began in the Tully Valley. Subsequent solution mining of the deeper halite beds caused further bedrock collapse, which was followed by land-surface subsidence and the opening of fractures in the bedrock walls adjacent to the east and west brine field areas. Land-surface subsidence was expressed within the brine field area through either widespread bulking subsidence over the long history of brine mining, nearly 100 years, or through more localized chimney subsidence where rapid sinkhole development occurred over the course of hours to days.

The subsurface movement and sinkhole development altered the structural integrity of the bedrock at the valley floor/wall margins. The subsidence created by the subsurface movement increased the horizontal strain in the bedrock along the adjacent valley wall, which led to the opening of pre-existing joints in the bedrock along the lower valley walls adjacent to each brine field area. On the basis of the spatial association of open fractures and adjacent sinkholes, especially in the east brine field, most of the subsidence-induced fracture development is associated with the rapid structural changes that follow chimneytype sinkhole collapse.

The correlation between open fractures adjacent to the brine field areas and joints measured in nearby bedrock exposures outside the influence of mining activity shows that the development of open fractures follows existing regional closedjoint orientations, some of which are linked to the Alleghanian Orogeny. Over the most recent decade, subsurface collapse has apparently stabilized, halting the development of additional subsidence features at the land surface and the further opening of valley-wall fractures.

By William R. Hackett ${ }^{1}$, Gayle C. Gleason ${ }^{2}$, and William M. Kappel ${ }^{3}$

${ }^{1}$ Department of Geology, University of Vermont, Burlington, VT. 05405. william.hackett@uvm.edu

${ }^{2}$ Department of Geology, SUNY College at Cortland, Cortland, N.Y. 13045. gayle.gleason@cortland.edu

${ }^{3}$ U.S. Geological Survey, Ithaca, N.Y. 14850. wkappel@ usgs.gov 


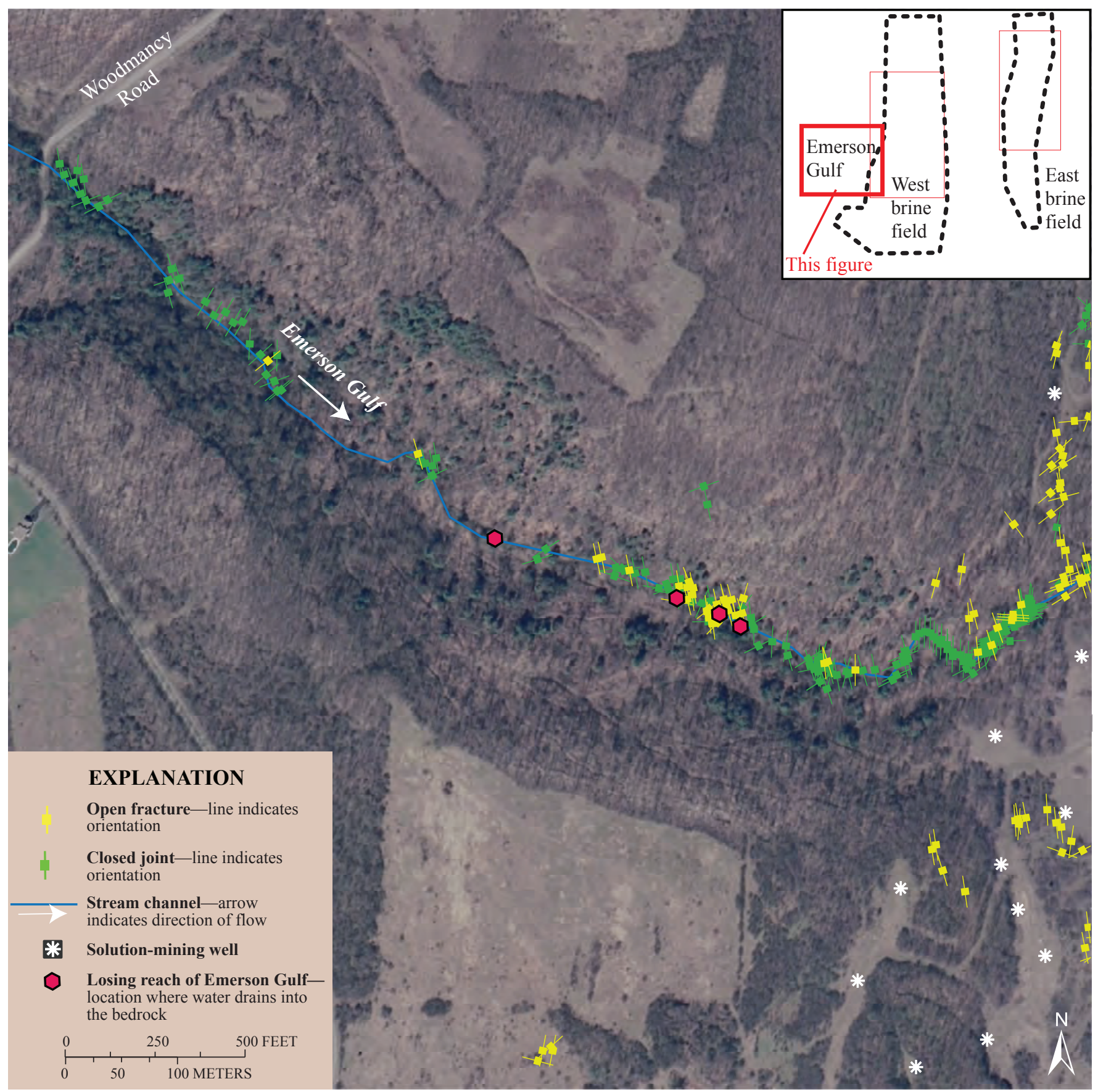

North American Datum of 1983; Universal Tranverse mercator projection, Zone 18N;

Orthoimage base from New York State Office of Cyber and Critical Infrastructure Coordination, Spring 2006.

Figure 7. Location of open fractures and closed joints within the streambed of Emerson Gulf, west of the west brine field in the Tully Valley, Onondaga County, N.Y. (Location shown in figure 1.) 
The opening of bedrock fractures along the perimeter of each brine field was established in reports of The Solvay Process Company (1950 and 1960), but the rate of fracture opening is not well known. During this study, a maple tree (Acer sp.) was found growing over an open fracture above the east brine field (fig. SB2-1). The use of dendrochronology (dating the growth of trees using tree rings) to determine the rate of fracture opening was attempted. Two aspects of the tree were studied: (1) the growth rings in the trunk (which can be used to evaluate changes in the rate of growth), and (2) the growth rings in the tree roots (especially those roots that became exposed to the air as the fracture opened and soil fell away from the roots).

The maple tree was almost 7 inches in diameter and was determined to be 79 years old in 2006, indicating that it began to grow in 1927. An assessment of the tree rings indicated that there was no evidence that growth of the tree had been compromised by the opening of the fracture (Dr. Thomas Yanosky, U.S. Geological Survey_Emeritus, written commun., 2008). In fact, the growth rings from 1985 to 2006 were wider than those of the previous years indicating healthy and vigorous growth despite the tree growing over the open fracture (fig. SB2-1). The outer rings of the exposed roots were branch-like in appearance and did not display any abrupt change in either ring width or ring anatomy that would indicate a rapid excavation of the roots. Rather, the exposure of the root to the air as a result of the widening of the fracture and the erosion of soil around the root seems to have been a gradual process. The outer rings of the roots were wide, similar to those of the main trunk, indicating vigorous recent growth.

The wood of maple trees is notorious for the presence of "pith flecks" (small pockets of callous tissue that develop when boring insects inflict minute damage to the cambium where sap flows). Each small fleck is within a single ring, and any one ring may have several flecks when examined along the entire ring circumference (fig. SB2-2A). When the tree is examined by stripping away the bark, one sees a long scar within the outer ring created as the beetle bored its way vertically up the cambium (fig. SB2-2B). Pith flecks were absent from the innermost rings of all the examined roots, but were numerous in the outer growth rings. A possible explanation for this phenomenon is that the beetles can easily access exposed roots but do not burrow into the soil and attack buried roots. Therefore, exposed roots close to the main trunk would contain a greater number of pith flecks in the outside rings; smaller roots more distant from the main trunk would contain fewer pith flecks in the outside rings and no pith flecks in the inside rings. This circumstance indicates that as the fracture opened under the center of the tree, soil fell into the opening fracture and the larger diameter roots close to the trunk of the tree became exposed earlier than the smaller diameter roots more distant from the tree trunk. The larger, more exposed roots were likely attacked periodically by boring beetles, whereas the more distant, still-buried roots were not. As the fracture continued to open, more distant roots became exposed and accessible to pith-boring beetles.

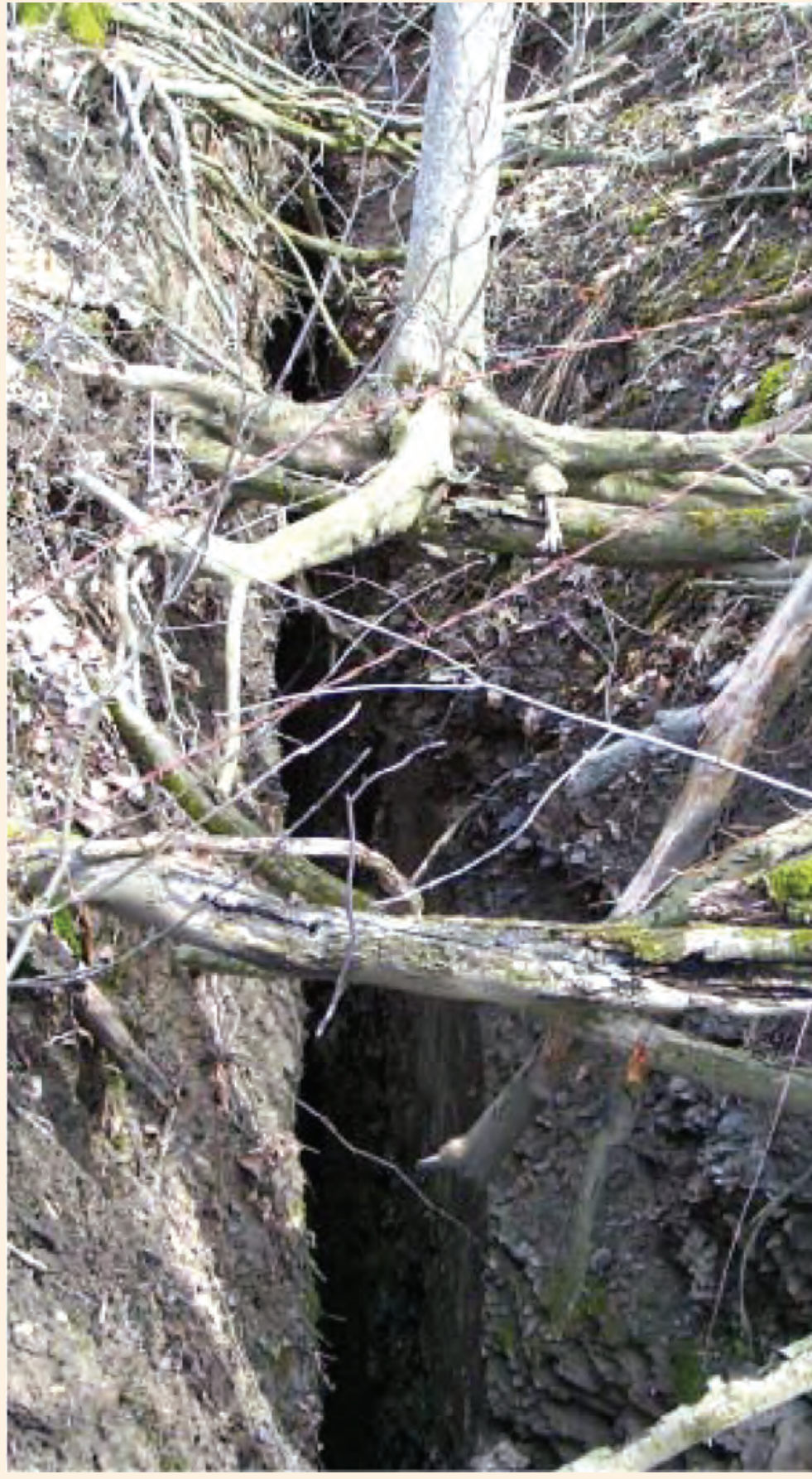

Figure SB2-1. Seven-inch diameter maple tree growing over an open be east brine field in the Tully Valley, Onondaga County, N.Y., 2006. 


\section{Using Tree Rings and Pith Flecks}

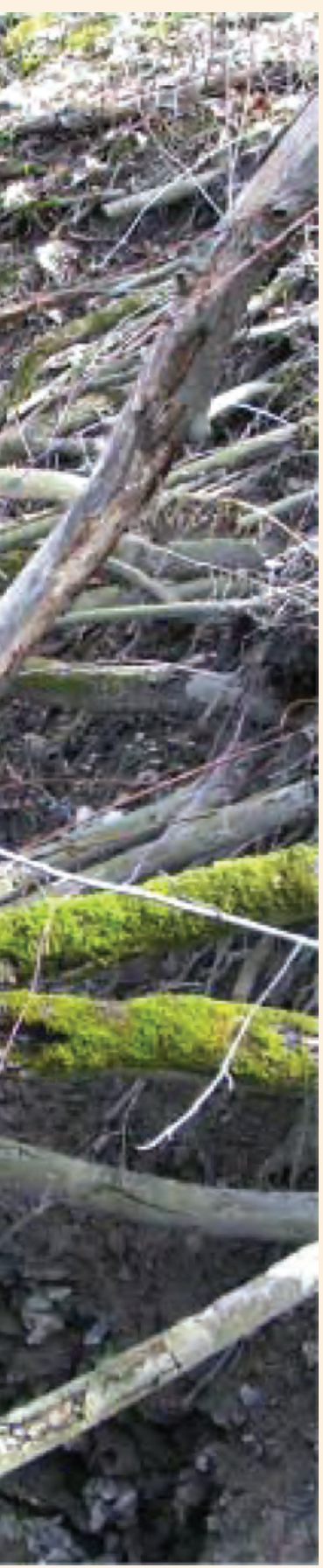

drock fracture above the
The following timeline of fracture development at this location was derived from the treering information:

(2) 1927-The tree germinates and begins to grow in soil over the bedrock fracture. The width of the fracture in the bedrock is unknown, but it is small enough that it does not affect the initial growth of the tree.

(2)1947-Twenty years after the tree began to grow, the fracture has opened enough to cause soil to fall into the fracture, allowing the tree roots near the base of the tree to take on a bark-like appearance. Beetles begin to create pith flecks in the outer annual ring of the exposed roots.

(01975-Forty-eight years after the tree began to grow, more soil had fallen away, exposing more of the roots while beetles continue to create pith flecks in the outer annual rings of the exposed roots.

(0)1986-Improved growth as determined by tree-ring analysis of both the trunk and roots are indicative of a slowing or cessation of fracture widening.

(0) 2006-2008 - Tree was removed in 2006 for analysis, and no fracture-width changes were noted at this location through 2008.

In summary, fracture development appears to have been slow at the soil surface when this tree germinated, but as it began to grow, bedrock fractures likely began opening on the eastern side of the valley sometime in the 1920s (The Solvay Process Company, 1950). Soil had slowly fallen away from the base of the tree by the late 1940s, and this particular fracture had continued to widen during the following 40-45 years. Currently (2009), the soil may be eroding away from the roots and cascading into the fracture opening, but the rate of soil erosion probably is much slower than when the bedrock fracture was actively widening.
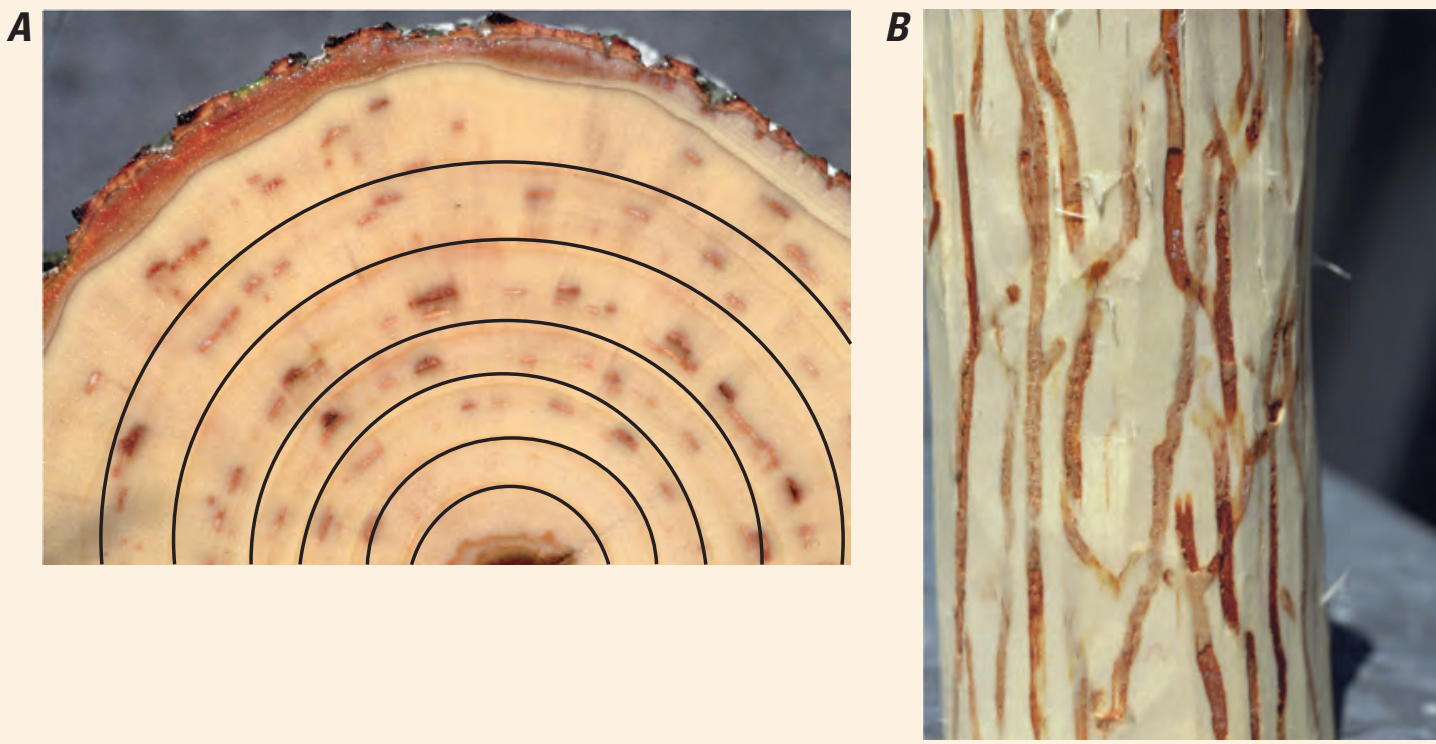

Figure SB2-2. Example of pith flecks (brown blotches) in a young willow tree, $(A)$ their arrangement in individual annual rings from a cross-section of the tree trunk (rings enhanced for clarity) and (B) pith channels along the tree trunk with the bark removed. 


\section{References}

CS Consulting Engineers, 1992, A projection of future geologic conditions in the Tully Valley, Onondaga County, New York, v. I, prepared in association with H\&A of New York for Allied-Signal, Inc.: Solvay, N.Y., 30 p.

DeGroff, E.R., 1950, Joint patterns in central New York: Syracuse, N.Y., Syracuse University, unpublished master's thesis, $75 \mathrm{p}$.

Engelder, T., and Geiser, P., 1980, On the use of regional joint sets as trajectories of paleostress fields during the development of the Appalachian Plateau, New York: Journal of Geophysical Research, no. 85, p. 6319-6341.

Engelder, T., Haith, B.F., and Younes, A., 2001, Horizontal slip along Alleghanian joints of the Appalachian plateau: Evidence showing that mild penetrative strain does little to change the pristine appearance of early joints: Tectonophysics, no. 336, p. 31-41.

Fernández, G.G., 1992, Report on brine field subsidence: Appendix B, in A projection of future geologic conditions in the Tully Valley, Onondaga County, New York, v. IIAppendices: Solvay, N.Y., CS Consulting Engineers in association with H\&A of New York for Allied-Signal, Inc., $19 \mathrm{p}$.

Kappel, W.M., 2000, Salt production in Syracuse, New York ("the salt city") and the hydrogeology of the Onondaga Creek valley: U.S. Geological Survey Fact Sheet FS 139-00, 8 p.

Kappel, W.M., and Miller, T.S., 2003, Hydrogeology of the Tully Trough: Southern Onondaga County and Northern County, New York: U.S. Geological Survey Water-Resources Investigations Report 03-4112, $16 \mathrm{p}$.
Parker, J.M., 1942, Regional systematic jointing in slightly deformed sedimentary rocks: Geologic Society of America Bulletin, no. 53, p. 381-408.

Rickard, L.V., 1969, Stratigraphy of the Upper Silurian Salina Group, New York, Pennsylvania, Ohio and Ontario: New York State Museum and Science Service, Map and Chart Series, no. 12.

Rogers, W.B., 1991, The missing record-Tertiary Period, in Isachsen, Y.W., Landing, E., Lauber, J.M., Rickard, L.V., and Rogers, W.B., eds., Geology of New York-A simplified account: Albany, N.Y., New York State Museum, Educational Leaflet no. 28 , p. $157-160$.

The Solvay Process Company, 1950, Tully brine well data and brief history: Memorandum (La-3-R): Syracuse, N.Y., Solvay Process Division-Allied Chemical and Dye Corporation, Syracuse, N.Y., 25 p.

The Solvay Process Company, 1960, Investigation-

Tully brine field - A history of development:

Memorandum (8-JEM-119), Syracuse, N.Y., Solvay Process Division-Allied Chemical and Dye Corporation, 17 p.

Van Sambeek, L.L., 1996, Retsof mine surface subsidence_-Post flooding update: Rapid City, S.D., Topical Report RSI-0699, RE/SPEC, Inc., 33 p.

Yanosky, T., and Kappel, W.M., 1998, Tree rings record 100 years of hydrologic change within a wetland: U.S. Geological Survey Fact Sheet 057-97, 4 p.

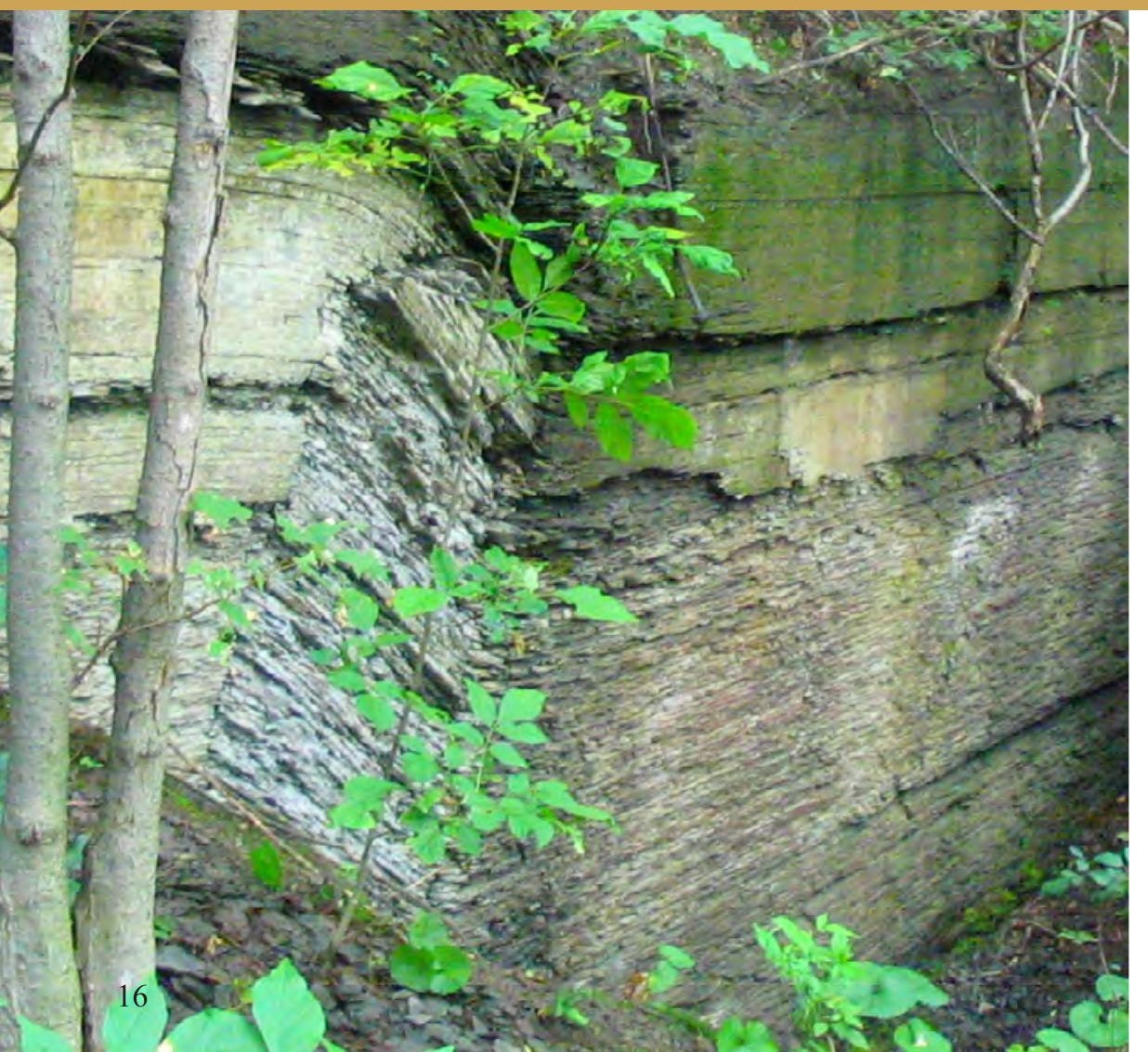

For additional information write to: New York Water Science Center U.S. Geological Survey 30 Brown Rd. Ithaca, N.Y. 14850

Information requests: (518) 285-5602 or visit our Web site at: http://ny.water.usgs.gov

For more information on the USGS--the Federal source for science about the Earth, its natural and living resources, natural hazards, and the environment: World Wide Web: http://www.usgs.gov Telephone: 1-888-ASK-USGS

Any use of trade, product, or firm names is for descriptive purposes only and does not imply endorsement by the U.S. Government. 